\title{
Flooding, Leaf Gas Exchange, and Growth of Mango in Containers
}

\author{
Kirk D. Larson and Bruce Schaffer \\ Tropical Research and Education Center, IFAS, University of Florida, Homestead, FL 33031
}

\author{
Frederick S. Davies \\ Fruit Crops Department, IFAS, University of Florida, Gainesville, FL 32611
}

\begin{abstract}
Additional index words. anoxia, carbon assimilation, lenticel hypertrophy, Mangifera indica, photosynthesis, stomatal conductance, transpiration, water potential

Abstract. The effect of flooding on container-grown 'Tommy Atkins' mango (Mangifera indica L.) trees on two rootstock, and on container-grown seedling 'Peach' mango trees, was investigated by evaluating vegetative growth, net gas exchange, and leaf water potential. In general, flooding simultaneously reduced net $\mathrm{CO}_{2}$ assimilation (A) and stomatal conductance ( $g_{s}$ ) after 2 to 3 days. However, flooding did not affect leaf water potential, shoot extension growth, or shoot dry weight, but stem radial growth and root dry weight were reduced, resulting in larger shoot : root ratios for flooded trees. Mortality of flooded trees ranged from $0 \%$ to $45 \%$ and was not related to-rootstock scion combination. Hypertrophied lenticels were observed on trees that survived flooding but not on trees that died. The reductions in gas exchange, vegetative growth, and the variable tree mortality indicate that mango is not highly flood-tolerant but appears to possess certain adaptations to flooded soil conditions.
\end{abstract}

The most rapid physiological responses of fruit trees to flooding are a reduction in $\mathrm{g}_{\mathrm{s}}$ and $\mathrm{A}$ (Andersen et al., 1984a, 1984b; Crane and Davies, 1989; Davies and Flore, 1986; Schaffer and Ploetz, 1989; Smith and Ager, 1988; Syvertsen et al., 1983). Woody plants often exhibit a decrease in A and $\mathrm{g}_{\mathrm{s}}$ within 1 to 3 days after flooding, although longer flooding durations are required for reductions in growth (Andersen et al., 1984a; Crane and Davies, 1989).

Tolerance of mangos to flooding is not well-known. Some reports indicate that mango trees require good soil drainage for adequate growth and yield (Alfonsi and Brunini, 1980; Samson, 1986), whereas other reports indicate that they are flood tolerant (Chandler, 1958; Jawanda, 1961; Young and Sauls, 1981). Therefore, experiments were initiated to determine the physiological and growth responses of mango trees in containers to flooding using leaf gas exchange, leaf water potential, vegetative growth, and tree survival as stress indicators.

\section{Materials and Methods}

Flooding, net gas exchange, and vegetative growth Expt. 1). Thirty 4-year-old 'Tommy Atkins' mango trees, $\approx 2.25 \mathrm{~m}$ high (15 on 'Turpentine' rootstock and 15 on an unknown seedling rootstock), were grown outdoors in 57-liter containers with Krome very gravelly loam soil (loamy-skeletal, carbonatic, hyperthermic Lithic Rendoll). Trees were exposed to three treatments in Oct. 1989; 1) nonflooded (control), 2) flooded for 14 days (14DF), or 3 ) flooded for 28 days (28DF). Five single-tree replicates of each rootstock were used for each experimental treatment. Thus, there was a $2 \times 3$ factorial arrangement of treatments (two rootstock, three flooding treatments) that was replicated five times in a split-plot design, with rootstock as the main plot and flooding treatment as the subplot. Plants were flooded by submerging the containers in plastic-lined metal tubs filled with tap water. Water levels in the tubs were maintained $\approx 10 \mathrm{~cm}$

\footnotetext{
Received for publication 15 Mar. 1990. Florida Agricultural Experiment Station Journal Series no. R-00568. This research was funded, in part, by U.S. Dept. of Agriculture Special Grant no. 89-34135-4573. We thank P.C. Andersen, J.H. Crane, and J.P. Syvertsen for critical review of this manuscript. The cost of publishing this paper was defrayed in part by the payment of page charges. Under postal regulations, (his paper therefore must be hereby marked advertisement solely to indicate this fact.
}

above the soil surface. Control trees were watered about twice a week to maintain soil moisture near container capacity.

Diurnal air temperatures fluctuated between 22 and 34C during the experiment. Initially, soil temperatures were higher for the nonflooded than the flooded treatments, but after 3 days mean soil temperatures at 5 -cm depth were $\approx 34 \mathrm{C}$ for all treatments.

For flooded trees, soil redox potential (Eh) was monitored periodically at a soil depth of $15 \mathrm{~cm}$ using a silver/silver chloride reference electrode (Model RC5, Jensen Instruments, Tacoma, Wash.), an oxygen meter (Model P5E, Jensen Instruments) and four platinum-tipped microelectrodes, as described by Crane and Davies (1988). The platinum tips of the microelectrodes were fused to a 3-mm brass alloy rod and the junction sealed in epoxy resin (Bohn, 1971; Mann and Stolzy, 1971). Accuracy of each microelectrode was checked before use by measuring the electrical potential of $\mathrm{pH}$-buffered quinhydrone solutions (Bohn, 1971).

For all trees, $\mathrm{A}, \mathrm{g}_{\mathrm{s}}$, transpiration $(\mathrm{E})$, internal $\mathrm{CO}_{2}$ concentration $\left(\mathrm{C}_{\mathrm{i}}\right)$ and leaf temperatures were determined with a portable infrared gas analyzer (Analytical Development, Hoddeson, Herts., U.K.), as described by Schaffer and O'Hair (1987). All gas exchange determinations were made at photosynthetic photon flux $500 \mu \mathrm{mol} \cdot \mathrm{s}^{-1} \cdot \mathrm{m}^{-2}$, which is above light saturation for mango (Schaffer and Gaye, 1989). Air flow into the leaf chamber was at $375 \mathrm{ml} \cdot \mathrm{min}^{-1}$. In the leaf chamber, $\mathrm{CO}_{2}$ concentration was $346 \pm 9 \mu \mathrm{mol} \cdot \mathrm{mol}^{-1}$; air was at $29.8 \pm 5.5 \mathrm{C}$; and mean vapor pressure was $1.1 \mathrm{kPa}$ (ranging from 0.9 to 2.1 $\mathrm{kPa}$ ). Gas exchange calculations were based on those described by Jarvis (1971) and von Caemmerer and Farquhar (1981). Repeated measurements showed little difference in net gas exchange among leaves of similar age in individual mango trees (data not shown). Therefore, one fully mature, sun-exposed leaf on the most recent, mature growth flush of each tree was used for gas exchange determinations. Measurements were made between 1000 and $1300 \mathrm{HR}$ (EST) before flooding, at 2 and 5 days of flooding, and at about weekly intervals for 65 days thereafter.

Stem radial growth was determined by measuring stem cir-

\footnotetext{
Abbreviations: A, net $\mathrm{CO}_{2}$ assimilation; $\mathrm{C}_{\mathrm{i}}$, internal $\mathrm{CO}_{2}$ concentration; $\mathrm{E}$,
} transpiration; $\mathrm{g}_{s}$, stomatal conductance. 
cumferences $10 \mathrm{~cm}$ above the graft union before flooding and 28,56 , and 84 days after flooding was imposed. Shoot extension growth was determined on two actively growing, sun-exposed shoots per tree. Shoots were measured before flooding and extension growth was determined 84 days after flooding was imposed.

Gas exchange and growth data were analyzed by analysis of variance $(P \leq .05)$.

Flooding and leaf water potential (Expt. II). Twelve 4-yearold 'Tommy Atkins' mango trees, six on 'Turpentine' rootstock and six on a seedling rootstock, $\approx 2.25 \mathrm{~m}$ high, were grown in 57-liter-containers in Krome very gravelly loam soil. On 7 Dec. 1989, trees were subjected to two flooding treatments as described in Expt. I: 1) nonflooded (control), and 2) continuously flooded for 14 days. Three single-tree replicates of each rootstock were used for each treatment. Thus, there was a $2 \times 2$ factorial arrangement of treatments, replicated three times in a split-plot design with rootstock as the main plot and flooding treatment as the subplot. Diurnal air temperatures fluctuated between 10 and $24 \mathrm{C}$ during the experiment, and flooded soil averaged $16 \mathrm{C}$.

Before flooding and at biweekly intervals for 2 weeks thereafter, $\mathrm{A}, \mathrm{g}_{\mathrm{s}}, \mathrm{E}$, and $\mathrm{C}_{\mathrm{i}}$ were determined at 1000-1300 HR for each tree. Gas exchange determinations were made as described in Expt. I., except that the leaf chamber was at $24.5 \pm 4.4 \mathrm{C}$, $\mathrm{CO}_{2}$ concentration was $345 \pm 6 \mu \mathrm{mol} \cdot \mathrm{mol}^{-1}$, and mean vapor pressure was $0.90 \mathrm{kPa}$ (ranging from 0.42 to $1.40 \mathrm{kPa}$ ). Immediately following gas exchange determinations, midday (1200$1400 \mathrm{HR}$ ) leaf water potentials were determined with a pressure chamber (Model 3000, Soil Moisture Equipment, Santa Barbara, Calif.) on three sun-exposed leaves of each tree (Scholander et al., 1965). Data were analyzed by a standard t test $(P$ $0.05)$.

Net gas exchange during the early stages of flooding (Expt. III). To examine the effects of flooding on gas exchange during the early stages of flooding, ten 1-year-old 'Peach' seedling mango trees, $\approx 60 \mathrm{~cm}$ high, were grown in 7.5 -liter containers in 1 peat : 1 perlite $(\mathrm{v} / \mathrm{v})$. Five replicate plants were flooded on 6 Sept. 1989 by submerging the containers in tap water in plastic tubs, and five replicate plants were maintained nonflooded. Nonflooded plants were maintained as described previously, but water levels were maintained $\approx 5 \mathrm{~cm}$ above the soil surface for flooded plants. The experimental design was a randomized complete block, with one tree from each treatment in each of five blocks. Determinations of $\mathrm{A}, \mathrm{g}_{\mathrm{s}}, \mathrm{E}$, and $\mathrm{C}_{\mathrm{i}}$ were made on two fully expanded, sun-exposed leaves of the most recent, mature growth flush of each tree at $1300 \mathrm{HR}$, immediately before plants were flooded. Thereafter, determinations were made at $1300 \mathrm{HR}$ on day 1 of flooding, at 1000, 1300, and 1600 HR on days 2 and 3, and at $1000 \mathrm{hr}$ on day 4 of flooding. For all trees, gas exchange was monitored as described in Expt. I, except for the following leaf chamber conditions: $\mathrm{CO}_{2}$ concentration was 340 $\pm 9 \mu \mathrm{mol} \cdot \mathrm{mol}^{-1}$, temperature was $31.4 \pm 5 \mathrm{C}$, and mean vapor pressure was $0.94 \mathrm{kPa}$ (ranging from 0.53 to $1.47 \mathrm{kPa}$ ). Data were analyzed by a standard $t$ test $(P \leq 0.05)$.

Flooding and growth (Expt. IV). One-year-old 'Peach' seedling mango trees $\approx 70 \mathrm{~cm}$ high were grown in 11.5 -liter containers in Krome very gravelly loam soil. Fifty trees were divided into four categories on the basis of height and basal stem diameters. Equal numbers of plants were randomly selected from each size category and placed into five groups of 10 plants each, so that there was no difference among the groups in mean height or stem diameter. One randomly selected group was immedi- ately harvested for determination of leaf area, total shoot length, length of new shoot growth flushes, and fresh and dry weights of leaves, new growth flushes, total shoot and roots, and for calculation of shoot : root ratios. The remaining groups were randomly assigned two treatments; 1) flooded by submerging the containers in plastic tubs, or 2) nonflooded (control), both as described in Expt. III. Thus, two replicates of 10 sample trees were assigned to each treatment in a randomized completeblock design. After 2 and 4 weeks of flooding, one group of plants in each treatment (flooded and nonflooded) was harvested. Mean leaf area (LICOR LI-3000 area meter; LI-COR, Lincoln, Neb.), total shoot length, and length of new shoot growth flushes were determined for trees in all groups upon harvest. Plants were oven-dried at $60 \mathrm{C}$ for 4 days and mean leaf dry weight, total shoot dry weight, dry weight of new shoot growth flushes, root dry weight, and root : shoot ratio were determined. Data were analyzed by a standard $t$ test $(P \leq 0.05)$.

\section{Results}

Flooding, net gas exchange, and vegetative growth Expt. 1). Within 3 days of flooding, mean Eh of the flooded soil was $+26 \mathrm{mv}$, indicative of anaerobic soil conditions (Gambrell and Patrick, 1978), and soil pH was 7.4. After 21 days of flooding, Eh and $\mathrm{pH}$ had stabilized at $-150 \mathrm{mv}$ and 7.0, respectively.

There was no interaction between rootstock and treatment for any of the variables measured $(P>0.05)$. Therefore, all 10 trees in a given treatment were pooled for statistical analyses. Leaf wilting and desiccation were observed for nine flooded trees within 3 to 4 days. With the exception of these nine trees (five from the 14DF, four from the 28DF treatment), lenticel hypertrophy was observed on submerged stems of all flooded trees within 5 to 7 days. The nine trees exhibiting leaf desiccation and shoot die-back were eliminated from the experiment by day 14 .

Within 2 days of flooding, A of flooded trees became negative, and $\mathrm{C}_{\mathrm{i}}, \mathrm{g}_{\mathrm{s}}$, and $\mathrm{E}$ and were $109 \%, 62 \%$, and $75 \%$ that of the nonflooded trees, respectively (Fig. 1). By day 58 (44 days after removal of plants from flooding), $\mathrm{A}, \mathrm{g}_{\mathrm{s}}$, and $\mathrm{E}$ of trees of the $14 \mathrm{DF}$ treatment were similar to those of the controls, decreased on day 64 , and recovered again by day 70 . By day 70 , $\mathrm{A}, \mathrm{g}_{\mathrm{s}}$, and $\mathrm{E}$ of trees in the 28DF treatment were lower, and $\mathrm{C}_{\mathrm{i}}$ was higher, than those of either the controls or the trees in the 14DF treatment. Leaf temperatures of flooded plants were 1 to $2 \mathrm{C}$ higher than leaf temperatures of nonflooded plants (data not shown).

Twenty-eight days after submergence, stem radial growth of trees in the $14 \mathrm{DF}$ and $28 \mathrm{DF}$ treatments was similar, but was $40 \%$ and $59 \%$, respectively, of that of the nonflooded trees (Fig. 2). Fifty-six days after submergence, stem radial growth of trees in the $14 \mathrm{DF}$ and $28 \mathrm{DF}$ treatments was $31 \%$ and $46 \%$, and by day 84 was $37 \%$ and $45 \%$, respectively, of that of the nonflooded trees. There was no difference among treatments in shoot extension growth (data not shown).

After several weeks, infestations of bark-boring ambrosia beetles (Xyloborus spp., Coleoptera:Scolytidae) were noted in all flooded trees. Such an attack often indicates elevated ethanol concentrations in the xylem sap (Cade et al., 1970). No infestations occurred on nonflooded trees.

Flooding and leaf water potential (Expt. II). Rootstock did not affect water potential or net gas exchange of flooded and nonflooded trees $(P>0.05)$. Therefore, the six trees in each treatment were pooled for statistical analyses. For flooded trees, A decreased within 7 days of flooding (data not shown) and 

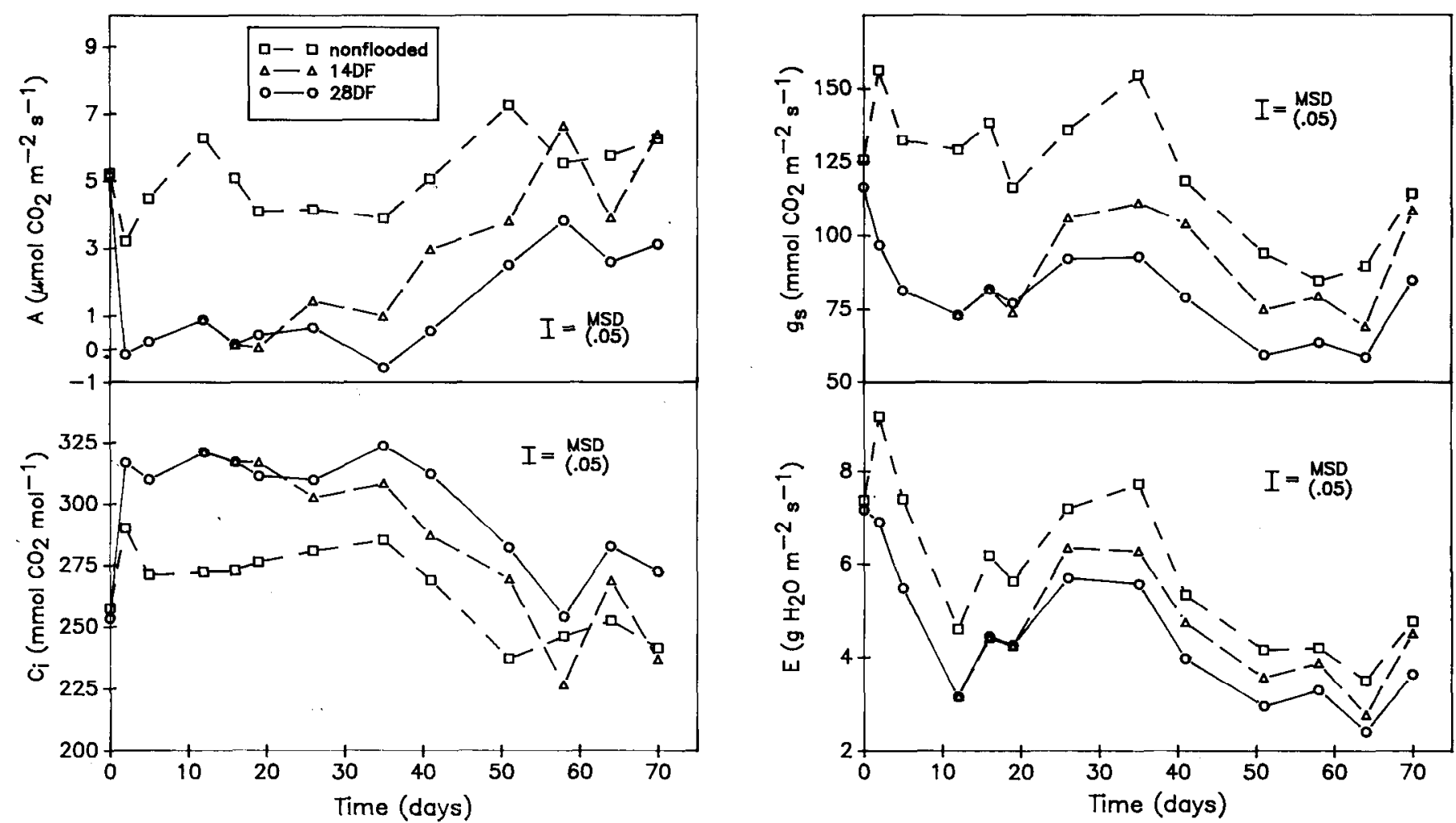

Fig. 1. Mean A, $\mathrm{g}_{\mathrm{s}}, \mathrm{C}_{\mathrm{i}}$, and $\mathrm{E}$ of 'Tommy Atkins' mango trees flooded for 0 , 14, or 28 days. Vertical lines represent pooled MSD according to Wailer-Duncan multiple range $t$ test $(P \leq 0.05)$.

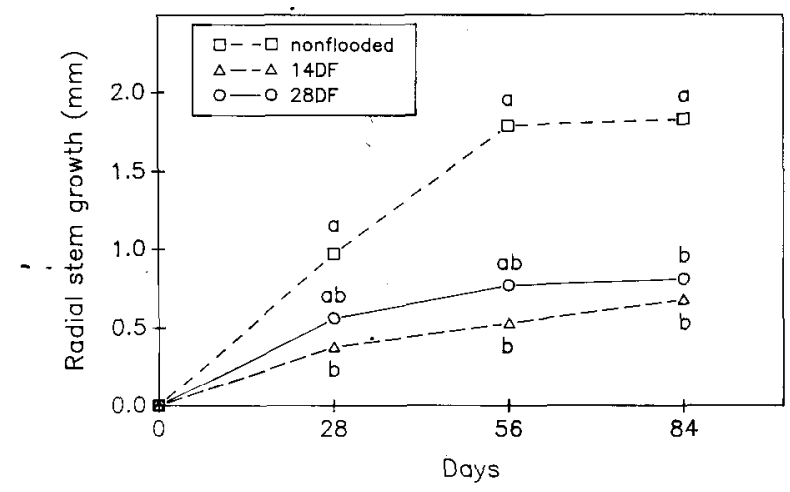

Fig. 2. Mean radial stem growth of 'Tommy Atkins' mango trees flooded for 0,14 , or 28 days. Different letters denote significant difference between treatments $(P \leq 0.05)$.

remained lower than that of the nonflooded trees for the remainder of the experiment. Flooding had no influence on leaf water potential, which averaged $-0.2 \mathrm{MPa}$, over the course of the experiment (data not shown). There were no visual symptoms of plant stress, such as leaf dessication or wilting, over the course of the experiment. Lenticel hypertrophy was noted on the submerged stems of five of the seven flooded trees after $\approx 10$ days of flooding.

Net gas exchange during early stages of flooding (Expt. III). Flooded trees had simultaneous decreases in $\mathrm{A}, \mathrm{E}$, and $\mathrm{g}_{\mathrm{s}}$, and an increase in $\mathrm{C}_{\mathrm{i}}$, by the morning of the $3 \mathrm{~d}$ day of flooding (Fig. 3). In general, the difference in A between flooded and nonflooded plants decreased over the course of day 3 before increasing by day 4 . Hypertrophied lenticels were observed on the submerged stems of all flooded trees after 4 to 5 days of flooding.
Flooding and growth (Expt. IV). Leaf area, leaf dry weight, total shoot length, length of new growth flushes, dry weight of new growth flushes (data not shown), and total shoot dry weight (Fig. 4) were similar for flooded and nonflooded trees on any harvest date. Two and 4 weeks after submergence, root dry weights of flooded trees were significantly reduced, and were $76 \%$ (week 2) and 66\% (week 4), respectively, of the nonflooded trees. The initial shoot : root ratio was 2.38. After 2 weeks, shoot : root ratios of non flooded and flooded trees were 2.72 and 3.80, respectively. By week 4, shoot : root ratios were 2.79 and 4.18 for nonflooded and flooded trees, respectively. There was no tree mortality in any treatment, and hypertrophied lenticels were observed in all flooded trees after 3 to 4 days of flooding.

\section{Discussion}

Greater tree mortality and a more rapid decrease in A were observed in Expt. I than in a previous study of mango flooding (Larson et al., 1989) or than in Expt. II. Although Expt. I and the previous study were conducted under similar environmental conditions, trees in the previous study had been recently transplanted into 57-liter containers, whereas trees in Expt. I were maintained in the same containers for 1.5 years and were more root-restricted.

In Expt. II, A was not reduced until 7 days after submergence and no visible symptoms of flooding stress (i. e., leaf desiccation, wilting) were observed in any of the flooded trees. The cooler temperatures and shorter days during this experiment may have moderated the flooding response. Slower growth rates and reduced shoot and root respiration rates (not measured) due to cooler temperatures also may have affected the flooding response.

The stomatal response of flooded mangos in the present study 

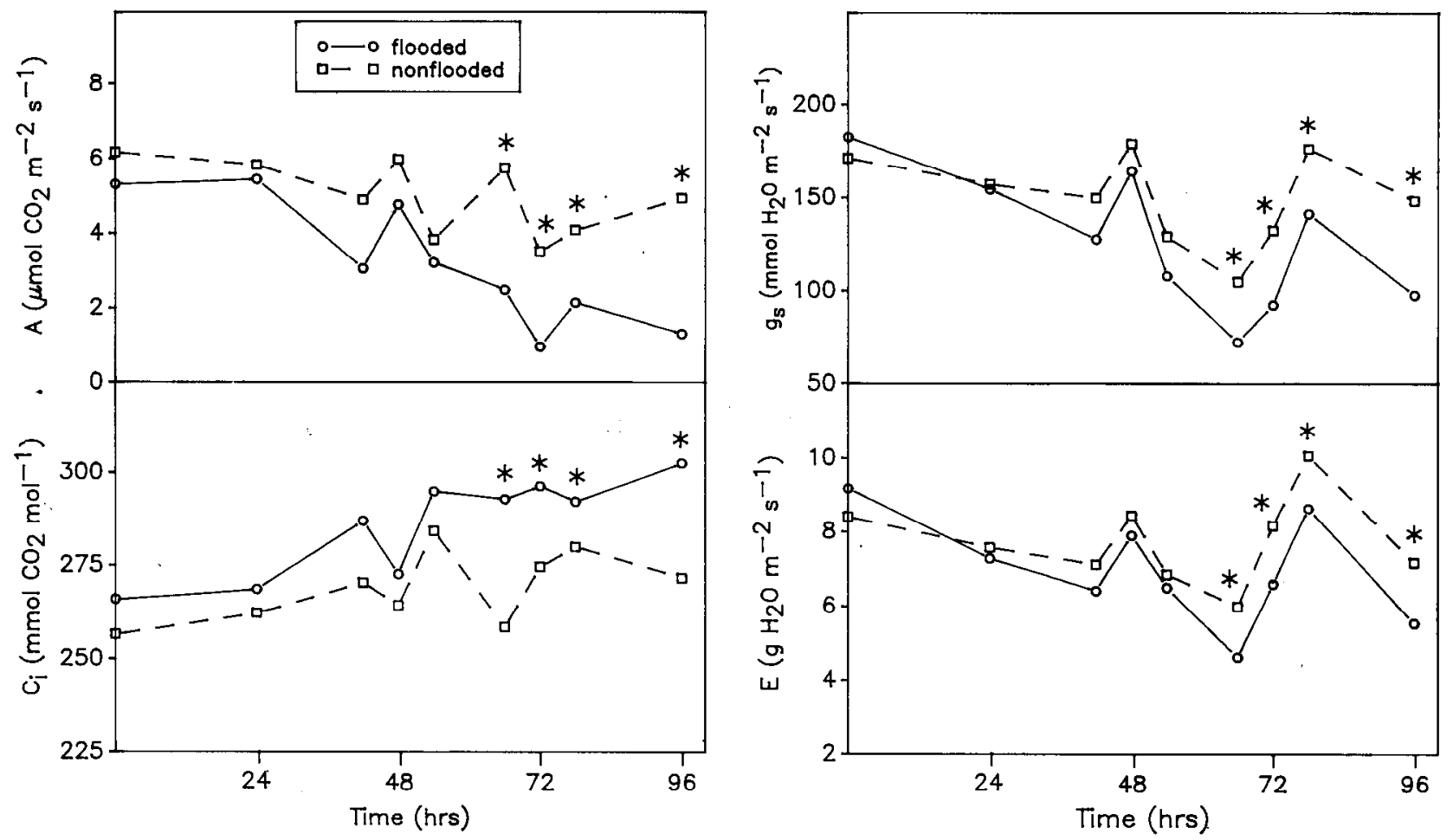

Fig. 3. Mean $\mathrm{A}, \mathrm{g}_{s}, \mathrm{C}_{\mathrm{i}}$, and $\mathrm{E}$ of flooded and nonflooded 'Peach' mango trees. Asterisks denote significant difference between treatments $(P \leq 0.05)$.

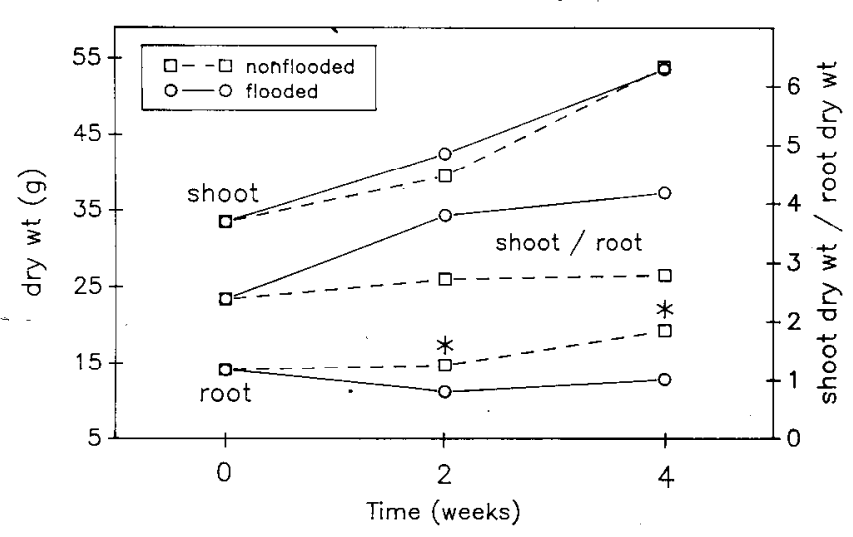

Fig. 4. Mean shoot and root dry weights, and shoot dry weight : root dry weight ratios of flooded and nonflooded 'Peach' mango trees. Asterisks denote significant difference between treatments $(P \leq 0.05)$.

(Fig. 1) differs from that of flood-tolerant species in which stomata reopen after 1 to 2 weeks of flooding (Kozlowski and Pallardy, 1984). Flood-induced stomatal closure has been attributed to decreases in leaf water potential resulting from decreased water uptake by the roots (Heincke, 1932; Kozlowski and Pallardy, 1984), possibly as a result of decreased cell membrane permeability under anaerobiosis (Bradford and Hsiao, 1982). However, as in Expt. II, stomatal closure of flooded plants occurred without reductions in leaf water potential (Andersen et al., 1984b; Bradford and Hsiao, 1982; Kozlowski and Pallardy, 1984; Smith and Ager, 1988).

In some flooding studies, decreases in A have been attributed primarily to stomatal closure (Kozlowski and Pallardy, 1984). In our study, the increase in $\mathrm{C}_{\mathrm{i}}$, concomitant with decreased $\mathrm{A}$ and $g_{s}$, suggested that nonstomatal factors may have been influencing carbon assimilation (Farquhar and Sharkey, 1982).
Although a previous study showed a reduction of mango shoot extension growth with long-term (110 days) flooding (Larson et al., 1989), the shorter durations of flooding in Expt. I were apparently insufficient to reduce shoot extension growth. However, similar to previous observations (Larson et al., 1989), stem radial growth was affected by flooding in the present study. Since mango growth flushes are often restricted to certain shoots in one part of the tree (Young and Sauls, 1981), stem radial growth measurements are a more sensitive indicator of tree growth than are measurements of shoot extension growth. An increased shoot : root ratio has often been observed in flooded woody plants, reflecting a greater sensitivity of root than shoot growth to flooding stress (Kozlowski, 1984). Inhibition of root growth with flooding is characteristic of flood-intolerant species (Kozlowski, 1984).

Lenticel hypertrophy occurs in several woody plant species subjected to flooding (Andersen et al., 1984a; Kawase, 1981; Kozlowski, 1984) and is thought to enhance $\mathrm{O}_{2}$ diffusion to roots (Kozlowski, 1984) or eliminate potentially toxic metabolizes such as ethanol, acetaldehyde, or ethylene (Chirkova and Gutman, 1972). Development of hypertrophied lenticels, however, does not necessarily confer flood-tolerance. Andersen et al. (1984a) observed lenticel hypertrophy on submerged stems of flood-intolerant Prunus persica. Profuse lenticel hypertrophy occurred on stems of mango trees that survived flooding, but there was little or no stem hypertrophy with mango trees that succumbed to flooding stress. Furthermore, when hypertrophied lenticels of flooded mango trees were covered, the trees died within 3 days (K.D.L. et al., unpublished data). Thus, hypertrophied lenticels appear necessary for mango tree survival under prolonged flooding, but their exact role in gas exchange or in the elimination of metabolic end products is not clear.

The ability of mango trees to survive prolonged flooding is variable and may be related to environmental conditions and the 
development of hypertrophied lenticels in individual trees. In previous studies, mango trees survived flooding for 110 days or more (Larson et al., 1989). For trees that survive flooding, the reductions in gas exchange and stem radial growth and the slow post-flood recovery with respect to gas exchange and growth indicate that this species is able to adapt to flooded soil conditions but is not highly flood-tolerant.

\section{Literature Cited}

Alfonsi, R.R. and O. Brunini. 1980. Aptidao ecologica para a mangueira, p. 23-33. In: L.C. Donadio (ed.). Anais do I simposio Brasileiro sobre a cultura da mangueira. UNESP, Sao Paulo, Brasil.

Andersen, P. C., P.B. Lombard, and M.N. Westwood. 1984a. Effect of root anaerobiosis on the water relation of several Pyrus species. Physiol. Plant. 62:245-252.

Andersen, P. C., P.B. Lombard, and M.N. Westwood. 1984b. Leaf conductance, growth, and survival of willow and deciduous fruit tree species under flooded soil conditions. J. Amer. Sot. Hort. Sci. 109:132-138.

Bohn, H.L. 1971. Redox potentials. Soil Sci. 112:39-45.

Bradford, K.J. and T.C. Hsiao. 1982. Stomata] behavior and water relations of waterlogged tomato plants. Plant Physiol. 70:1508-1513.

Cade, S. C., B.F. Hrutfiord, and R.I. Gara. 1970. Identification of a primary attractant for Gnathotrichus sulcatus isolated from Western hemlock logs. J. Econ. Entomol. 63:1014-1015.

Chandler, W.H. 1958. Evergreen orchards, Lea and Febiger, Philadelphia, Pa.

Chirkova, T.V. and T.S. Gutman. 1972. Physiological role of branch lenticels in willow and poplar under conditions of root anaerobiosis. Soviet Plant Physiol. 19:289-295.

Crane, J.H. and F.S. Davies. 1988. Periodic 'and seasonal flooding effects on survival, growth, and stomatal conductance of young rabbiteye blueberry plants. J. Amer. Soc. Hort. Sci. 113:488-493.

Crane, J.H. and F.S. Davies. 1989. Flooding responses of Vaccinium species. HortScience 24:203-210.

Davies, F.S. and J.A. Flore. 1986. Flooding, gas exchange and hydraulic conductivity of highbush blueberry. Physiol. Plant. 67:545551.

Farquhar, G.D. and T.D. Sharkey. 1982. Stomata] conductance and photosynthesis. Annu. Rev. Plant. Physiol. 33:317-345.

Gambrell, R.P, and W.H. Patrick, Jr. 1978. Chemical and microbiological properties of anaerobic soils and sediments, p. 375-423, In: D.D. Hook and R.M.M. Crawford (eds.). Plant life and anaerobic environments. Ann Arbor Sci. Press, Ann Arbor, Mich.
Heincke, A.J. 1932. The effect of submerging the roots of apple trees at different times of the year. Proc. Amer. Soc. Hort. Sci. 29:205207.

Jarvis, P.G. 1971. The estimation of resistance to carbon dioxide transfer, p. 566-631. In: K. Sestak, J. Catsky, and P.G. Jarvis (eds.). Plant photosynthetic production. Manual of methods. Junk. The Hague, Netherlands.

Jawanda, J.S. 1961. The effect of waterlogging on fruit trees. Punjab. Hort. J. 1:150-152.

Kawase, M. 1981. Anatomical and morphological adaptation of plants to waterlogging. HortScience 16:30-34.

Kozlowski, T.T. 1984. Responses of woody plants to flooding, p. 129163. In: T.T. Kozlowski (ed.). Flooding and plant growth. Academic, New York.

Kozlowski, T.T. and S.G. Pallardy. 1984. Effect of flooding on water, carbohydrate, and mineral relations, p. 165-193. In: T.T. Kozlowski, (ed.). Flooding and plant growth. Academic, New York.

Larson, K. D., B. Schaffer, and F.S. Davies. 1989. Flooding, carbon assimilation and growth of mango trees, Amer. Soc. Hort. Sci. 1989 Annu. Mtg., Tulsa, Okla., Program and Abstr. p. 126.

Mann, L.D. and L.H. Stolzy. 1971. An improved construction method for platinum electrodes. Proc. Soil Sci. Soc. Amer. 36:583-584

Samson, J.A. 1986. Tropical fruits. Longman, New York.

Schaffer, B. and G.O. Gaye. 1989. Gas exchange, chlorophyll and nitrogen content and mango leaves as influenced by light environment. HortScience 24:507-509.

Schaffer, B. and S. O'Hair. 1987. Net $\mathrm{CO}_{2}$ assimilation of taro and cocoyam as affected by shading and leaf age. Photosynthesis Res. 11:245-251.

Schaffer, B. and R.C. Ploetz. 1989. Gas exchange characteristics as indicators of damage thresholds for phytophthora root rot of flooded and nonflooded avocado trees. HortScience 24:653-655.

Scholander, P. F., H.T. Hammel, E.D. Bradstreet, and E.A. Hemmingsen. 1965. Sap pressure in vascular plants. Science 48:339345.

Smith, M.W. and P.L, Ager. 1988. Effects of soil flooding on leaf gas exchange of seedling pecan trees. HortScience 23:370-372.

Syvertsen, J. P., R.M. Zablotowicz, and M.L. Smith, Jr. 1983. Soil temperature and flooding effects on two species of citrus. I. Plant growth and hydraulic conductivity. Plant and Soil 72:3-12.

von Caemmerer, S. and G.D. Farquhar. 1981. Some relationships between biochemistry of photosynthesis and gas exchange of leaves. Planta 153:376-387.

Young, T.W. and J.W. Sauls. 1981. The mango industry in Florida. Fla. Coop. Ext. Serv. Bul. 189, Univ. of Fla., Gainesville. 